\title{
性能関数のモーメント推定 \\ EVALUATION OF STATISTICAL MOMENTS FOR PERFORMANCE FUNCTIONS
}

\author{
趙 衍 剛*, 小野徹 郎** \\ Yan-Gang ZHAO and Tetsuro ONO
}

\begin{abstract}
In the fields of structural safety and structural dynamics, there are many areas in which it is often desirable to compute the first few statistical moments of a performance function. In previous studies, five- and seven-point estimates for statistical moments have been proposed, in which the estimating points are independent of the random variable in original space and high-order moments of the original random variables are not required. These methods have been verified to be generally efficient for estimating the first two moments of a function of random variables. In the present study, in order to improve the estimation accuracy for high-order moments, the general relationship between the weights and concentrations in arbitary number are derived, and the concentrations up to 21 points for a function of a single random variable as well as the formulas for the first six moments of a function of multiple random variables are presented. From several numerical examples, it is shown that high-order moments can be estimated with high accuracy using the proposed formulations.
\end{abstract}

Keywords: Response uncertainty, structural reliability, performance function, statistical moment, point estimates 応答不確定性、構造信頼性、性能関数、確率モーメント、点推定法

\section{1.はじめに}

近年，外力や抵抗に含まれている不確定性を考虑した信頼性設計 が取り入られる傾向にあり，日本建築学会でも，建築物の限界状態 設計指針（案）川が示されるに至っている。

構造物の性能（変形能力や動的応答など）は、外力や抵抗に含ま れている不確定性によってばらつきがあり、信頼性の考え方に立脚 した構造設計を目指すためには構造物の性能の不確定性を把握して おくことが肝要である。構造物の性能は、外力や抵抗に含まれてい る不確定性を表す確率変数の関数である性能関数として表され、そ の不確定性を把握するには性能関数の平均值と標準偏差などのモ一 メントを求める必要がある。

一方、構造信頼性解析における高次積率標準化手法|2|]1|およびモー メント法|4||5||6|では、破壊確率を求めるために性能関数の一種である 限界状態関数の高次モーメントを求めることも要求されている。

性能関数を確率変数ベクトル $\mathbf{X}$ の関数 $G(\mathbf{X})$ で表せば、上述の性能関 数のモーメントを求める問題は次の積分に帰着することができる。

$$
\begin{aligned}
\mu_{G} & =\int G(\mathbf{X}) f(\mathbf{X}) d \mathbf{X} \\
M_{k G} & =\int\left(G(\mathbf{X})-\mu_{G}\right)^{k} f(\mathbf{X}) d \mathbf{X} \text { for } k \geq 2
\end{aligned}
$$

ただし、 $\mu_{G}$ は $G(\mathbf{X})$ の平均值であり、 $M_{k G}$ は $G(\mathbf{X})$ の第k次中心モーメン トである。 $f(\mathbf{X})$ は $\mathbf{X}$ 結合確率密度関数である。

式(1) と式 (2)のモーメントを求める方法は、統計的解法としては モンテカルロ法、非統計的解法としては摂動法、テーラー展開法など がある[7-11]。モンテカルロ法では膨大な計算時間が必要であり、摂動 法とテーラー展開法では性能関数の導関数を計算する必要がある。こ れらの問題点を回避するために、2 点推定法 ${ }^{[12] 113]}$ と 3 点推定法 ${ }^{[14-17]}$ が提案されている。 2 ないし 3 点推定法は 2 ないし 3 点で評価される 重みのついた関数値を扱う方法であり、性能関数の陽的表現および 導関数を必要とせず、その簡便性の反面、2ないし 3 の推定点しか用 いないので、性能関数によって、推定精度を維持することが難しいこ とと、任意な確率変数に適用する一般性がない、などの問題点がある [181。筆者らは標準正規空間で $5 、 7$ 点の推定点と重みを提供し、性能

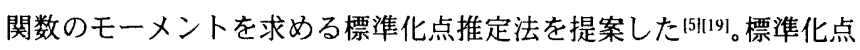
推定法では、推定点と重みは原空間の確率変数 $\mathbf{x}$ の分布に左右され ず、従来の 2 ないし 3 点推定法の上述の問題点をかなり改善している が、性能関数の非線形性の強さによって、5、7 点の推定点だけで は、高次モーメントを求めるには不十分である点が残っている。一 般には性能関数の不確定性を把握するには平均值と標準偏差の 2 次ま でのモーメントが分かれば良いが、モーメント法を用いて破壊確率を
* 名古屋工業大学 助教授・工博

** 名古屋工業大学 教授・工博
Assoc. Prof., Nagoya Institute of Technology, Dr. Eng.

Prof., Nagoya Institute of Technology, Dr. Eng. 
求めるには $3 、 4$ 次のモーメント、時には $5 、 6$ 次のモーメントが 必要となる121。本論文では性能関数の高次モーメントを求めるに必要 となる任意数の推定点と重みの一般的関係を提示し、21点までの推 定点と重みを提供するとともに、標準化点推定法の性能関数のモ一 メント推定における適応性を検討する。

\section{2. 標準化点推定法の概要}

本節では既に提案された標準化点推定法を点推定法の概念から概 説する。

点推定法は有限数の点で評価される重みのついた関数値を扱う方 法であり、確率変数 $x$ の分布形を $m$ 点に集中させると、推定点と重み は原則的には次の連立方程式を満足するように決められる。

$$
\begin{aligned}
& \sum_{j=1}^{m} P_{j}=1 \\
& \sum_{j=1}^{m} P_{j} x_{j}=\mu_{x} \\
& \sum_{j=1}^{m} P_{j}\left(x_{j}-\mu_{x}\right)^{k}=M_{k x} \text { for } k \geq 2
\end{aligned}
$$

$x$ を変数にもつ関数 $y=y(x)$ のモーメントは次のように計算される。

$$
\begin{aligned}
& \mu_{y}=\sum_{j=1}^{m} P_{j} y\left(x_{j}\right) \\
& M_{k y}=\sum_{j=1}^{m} P_{j}\left(y\left(x_{j}\right)-\mu_{y}\right)^{k} \text { for } k \geq 2
\end{aligned}
$$

ただし、 $x_{j}$ は推定点であり、 $P_{j}$ は $x_{j}$ に対応する重みである。

推定点の数 $m$ が奇数であれば、 $x_{j}$ とP のような $2 m-1$ 個の方程式が必要となり、 $x$ の $2 m-2$ 次モーメントが必要 となる。推定点の数 $m=2$ と $m=3$ のとき、推定点 $x_{j}$ と重み $P_{j}$ は $x$ の 4 次ま でのモーメントを用いる計算式で既に与えられている(12.17!。しかし、 確率変数の種類によって、推定点は確率変数の定義領域以外にある 場合があり、任意な確率変数に適用する一般性がなく、2、3の推 定点しか用いないので、性能関数によって、推定精度を維持するこ とが困難である。推定精度を向上させるためには推定点の数を増や すことが考えられるが、推定点と重みを求めるために確率変数 $x$ その ものの高次積率を用いなければならず、推定点数を増やすことは高 次積率の数が大きくなり(例えば 5 つの推定点を求めるには 8 次モ一 メントまで必要になる)、 $P_{j}$ と $x_{j}$ の一般計算式を求めるには問題があ る。

これらの欠点を改善するために、標準化点推定法|51|191では標準正規 空間で標準化推定点を求め、各標準化推定点でRosenblatt逆変換によ り原空間の推定点を求めて、性能関数のモーメントを求める。式(6) と式(7)に示した $y=y(x)$ の一メントは標準化点推定法で計算すると、 次式のようになる。

$$
\begin{aligned}
& \mu_{y}=\sum_{j=1}^{m} P_{j} y\left[\left(T^{-1}\left(u_{j}\right)\right]\right. \\
& M_{k y}=\sum_{j=1}^{m} P_{j}\left(y\left[\left(T^{-1}\left(u_{j}\right)\right]-\mu_{y}\right)^{k} \text { for } k \geq 2\right.
\end{aligned}
$$

ただし、 $u_{j}, P_{j}$ は標準化推定点とその対応する重みであり、 $T$ は Rosenblatt 変換である。

標準正規確率変数では、平均值が 0 、分布形が左右対称形になって いるので、推定点を求めることは容易である。さらに、求められた
標準化推定点は原空間の確率変数 $x$ の分布には左右されず、 $x$ の高次 モーメントを用いる必要がない。

標準正規確率変数のモーメント特徴を利用すれば、式 (4) と式 (5) は次式となり、

$$
\sum_{j=1}^{m} P_{j} u_{j}^{k}=0 \text { for odd } k
$$

$$
\sum_{j=1}^{m} P_{j} u_{j}^{k}=(k-1) ! ! \text { for even } k
$$

推定点と重みは比較的容易に得られる。

$m$ が小さいとき（例えば $m=5,7$ など)、推定点と重みは式(10) と式 (11)の連立方程式により求めることができるが、 $m$ が大きいとき式 (10)と式(11)の連立方程式の次数と個数とも大きくなり、推定点と重 みを求めることが難しくなる。

\section{3. 標準化点推定法の任意数の推定点と重み 3.1 推定点と重みの導出}

任意数の推定点と重みを導出するために、 $y=y(x)$ を直接標準正規確 率変数 $u$ の関数で表し、式 (9)に対して次の関数代替を行う。

$$
z(u)=\left(y\left[\left(T^{-1}(u)\right]-\mu_{y}\right)^{k}\right.
$$

$y=y(x)$ のーメントの定義と前述の点推定法の概念により、式 (9) は 次のように標準正規空間で表すことができる。

$$
\int z(u) \phi(u) d u=\sum_{j=1}^{m} P_{j} z\left(u_{j}\right)
$$

即ち、

$$
\int z(u) \exp \left(-\frac{1}{2} u^{2}\right) d u=\sqrt{2 \pi} \sum_{j=1}^{m} P_{j} z\left(u_{j}\right)
$$

ただし、 $\phi(u)$ はの確率密度関数である。

式 (14)の左辺はGaussian型積分 ${ }^{(20)}$ である。数值積分の原理 ${ }^{[20) ! よ ~}$ り、この種の積分は重み関数が $\exp \left(-u^{2} / 2\right)$ の直交多項式の分点と重み から次のように計算される。

$$
\int z(u) \exp \left(-\frac{1}{2} u^{2}\right) d u=\sum_{j=1}^{m} w_{j} z\left(u_{j}\right)
$$

ただし、 $u_{j}$ と $w_{j}$ はそれぞれ重み関数がexp $\left(-u^{2} / 2\right)$ の直交多項式である Hermite 多項式 $H_{e m}(u)$ (付録参照) の分点と重みであり、 $u_{j}$ は一次元 代数方程式 $H_{e m}(u)=0$ の根である。

式 (14) と式 (15)を比較することにより、標準化推定点法における 任意数 $m$ の推定点 $u_{j}$ はHermite 多項式 $H_{e m}(u)$ の分点、即ち $H_{e m}(u)=0$ の 根であることが分かる。以下 $u_{j}$ に対応する重み $P_{j}$ の計算式を導く。 $u=\sqrt{2} t$ とすれば式 (15) は次式のようになる。

$$
\int z(\sqrt{2} t) \exp \left(-t^{2}\right) d t=\frac{1}{\sqrt{2}} \sum_{j=1}^{m} w_{j} z(\sqrt{2} t)
$$

式 (16)の左辺は重み関数がexp(- $\left.t^{2}\right)$ の Gaussian 積分であり、次の 数値積分公式から計算される1200。

$$
\int z(\sqrt{2} t) \exp \left(-t^{2}\right) d t=\sum_{j=1}^{m} w^{\prime}{ }^{\prime} z\left(\sqrt{2} t_{j}\right)
$$

ただし、 $x_{j}$ と $w_{j}^{\prime}$ はそれぞれ重み関数が $\exp \left(-t^{2}\right)$ の直交多項式である Hermite多項式 $H_{m}(t)$ (付録参照) の分点之重みであり、任意数 $m$ の分 
点 $t_{j}$ に対応する重み $w_{j}^{\prime}$ は次式より計算される ${ }^{2201}$ 。

$$
w^{\prime}=\frac{2^{m-1} m ! \sqrt{\pi}}{m^{2} H_{m-1}^{2}\left(t_{j}\right)}
$$

式 (14)、式 (15)、式 (16) と式(17)を比較することにより、 $P_{j} 、 w_{j}$ と $w_{j}^{\prime}$ の間に次の関係が得られる。

$$
P_{j}=\frac{1}{\sqrt{2 \pi}} w_{j}=\frac{1}{\sqrt{\pi}} w_{j}^{\prime}
$$

$H_{n t}(t)$ と $H_{e m}(u)$ の間の次に示す関係式（付録参照）

$$
H_{m}(t)=2^{m / 2} H_{e m}(u)
$$

を式 (18)に代入し、式 (19) より、任意数 $m$ の推定点 $u_{j}$ に対応する重 み $P_{j}$ が次のように得られる。

$$
P_{j}=\frac{m !}{m^{2} H_{e m-1}^{2}\left(u_{j}\right)}
$$

奇数の $m$ に対しては、 $H_{e m-1}(0)=(m-2) !$ ! となり、中心点 $u_{j}=0$ に対応 する重み $P_{0}$ は次式から簡単に計算することができる。

$$
P_{0}=\frac{(m-1) ! !}{m ! !}
$$

例えば、 $m=3$ のとき、 $P_{0}=2 / 3 、 m=5$ のとき、 $P_{0}=8 / 15 、 m=7$ のとき、 $P_{0}=16 /$ 35、 $m=9$ のとき、 $P_{0}=128 / 315 、 m$ が大きくなればなるほど中心点の重 みが小さくなることが分かる。

上述の計算方法を用い、 $m=21$ までの推定点と重みはTable 1のよう に得られる。偶数と奇数の $m$ に対する重みと標準正規確率変数 $u$ の 確率密度関数 $\phi$ の関係をそれぞれ Fig. 1 と Fig. 2 に示す。

\section{2 標準化点推定法の精度の検討}

現実の性能関数は多種多様であり、一意的に検討することは難しい が、ここでは性能関数の非線形を表す一つの目安として、性能関数に 含まれる標準正規確率変数 $u$ の次数に関して検討する。

文献 [20]により、 $m$ 個の推定点に対しては、式 (17)の誤差は次式 で表すことができる。

$$
R_{m}=\frac{m ! \sqrt{\pi}}{(2 m) !} z^{(2 m)}(\sqrt{2} \xi) \quad-\infty<\xi<+\infty
$$

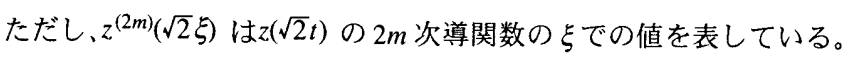
そは任意な実数である。

式 (23)によると、 $m$ 個の推定点では、関数 $z(u)=u^{2 m-1}$ の $2 m$ 次導関数 は0になるので、式 (17) の誤差 $R_{m}$ も0になる。即ち、 $m$ 個の推定点 では、関数 $z(u)=u^{2 m-1}$ の期待值を正確に推定することができる。従っ て、 $u$ の $r$ 次関数の期待値あるいは $u$ の 1 次関数の $r$ 次モーメントを 推定するには $(r+1) / 2$ 個の推定点が必要となる。

一般には、 $u$ の $r$ 次関数の $k$ 次モーメントを推定するに必要となる 推定点の数は次式で表わされる。

$$
m=\frac{k r+1}{2}
$$

例えば、 $u$ の 4 次関数の 4 次モーメントを推定するには、9個の推定 点が必要となり、6次関数の6次モーメントを推定するには、19個の 推定点が必要となる。

以上の検討によると、性能関数をRosenblett変換により標準正規空 間に変換すると、非線形性を表す目安としての $u$ の次数は判断しがた いが、Table 1 の $m=21$ までの推定点と重みを利用して、かなり強い非
線形性を有する性能関数のモーメントを推定することができる。

\section{4. 多変数の関数の点推定}

性能関数は多変数の関数であり、そのモ一メントは、原則的に前述 の推定点と重みを多重積分式に代入して計算できる。しかし、推定点 数が $m$ 、確率変数の数が $n$ あるとすると、 $m^{n}$ 回の関数值を計算する 必要がある。ここでは、次式で性能関数を近似する。

$$
G^{\prime}(\mathbf{X})=\sum_{i=1}^{n}\left(G_{i}-G_{\mu}\right)+G_{\mu}
$$

ただし、 $G_{\mu}$ と $G_{i}$ を次のように設定する。

$$
\begin{aligned}
G_{\mu} & =G(\boldsymbol{\mu}) \\
G_{i} & =G\left[T^{-1}\left(\mathbf{U}_{i}\right)\right]
\end{aligned}
$$

$\mathbf{U}_{i}=\left[u_{\mu 1}, u_{\mu 2}, \ldots, u_{i}, \ldots, u_{\mu n}\right]^{T} 、 \mu$ は平均値ベクトルであり、 $u_{\mu k}, k=1$, $\ldots, n$ は $\mu$ に対応する $u$ 空間の第 $k$ 個目の值である。

式(26)と(27)の定義により、G $G_{i}$ は $u_{i}$ だけの関数である。Rosenblatt 変換の特性により、 $\mathbf{x}$ の相関性と関係なく、Gi互いに独立になる。 従って、G'(X)の6 次までのモーメントは次式より表される。

$$
\begin{aligned}
& \mu_{G}=\sum_{i=1}^{n}\left(\mu_{i}-G_{\mu}\right)+G_{\mu} \\
& \sigma_{G}^{2}=\sum_{i=1}^{n} \sigma_{i}^{2} \\
& \alpha_{3 G} \sigma_{G}^{3}=\sum_{i=1}^{n} \alpha_{3 i} \sigma_{i}^{3} \\
& \alpha_{4 G} \sigma_{G}^{4}=\sum_{i=1}^{n} \alpha_{4 i} \sigma_{i}^{4}+6 \sum_{i=1}^{n} \sum_{j>i}^{1} \sigma_{i}^{2} \sigma_{j}^{2} \\
& \alpha_{5 G} \sigma_{G}^{5}=\sum_{i=1}^{n} \alpha_{5 i} \sigma_{i}^{5}+10 \sum_{i=1}^{n-1} \sum_{j>i}^{n} \sigma_{i}^{2} \sigma_{j}^{2}\left(\alpha_{3 i} \sigma_{i}+\alpha_{3 j} \sigma_{j}\right) \\
& \alpha_{6 G} \sigma_{G}^{6}=\sum_{i=1}^{n} \alpha_{6 i} \sigma_{i}^{6}+90 \sum_{i=1}^{n-2} \sum_{j>i}^{n-1} \sum_{k>j}^{n} \sigma_{i}^{2} \sigma_{j}^{2} \sigma_{k}^{2} \\
& \quad+15 \sum_{i=1}^{n-1} \sum_{j>i}^{n} \sigma_{i}^{2} \sigma_{j}^{2}\left(\alpha_{4 i} \sigma_{i}^{2}+\alpha_{4 j} \sigma_{j}^{2}+\frac{4}{3} \alpha_{3 i} \sigma_{i} \alpha_{3 j} \sigma_{j}\right)
\end{aligned}
$$

ここで $\mu_{i}, \sigma_{i}, \alpha_{r}$ はそれぞれ $G_{i}$ の平均値、標準偏差、及び無次元 $r$ 次モ一 メントである。 $G_{i}$ は $u_{i}$ だけの関数であるので, $\mu_{i}, \sigma_{i}, \alpha_{r i}$ は前節の各 式で計算する。

\section{5. 性能関数のモーメント推定}

\subsection{1 確率変数の場合の標準化点推定法の考察}

本論文の性能関数のモ一メント推定は 1 確率変数の関数のモーメン ト推定に基づいているので、次の 1 確率変数の簡単な関数を対象とし て、標準化点推定法の計算手順を示すとともに、1 確率変数の関数の モーメント推定に標準化点推定法の精度を考察する。

$$
y=x^{2}
$$

ただし、 $x$ は平均值が 1 の対数正規分布に従う確率変数である。

$x$ の変動係数 $V=0.2$ の時、 $\ln (x)$ の平均值と標準偏差はそれぞれ $\lambda=-$ 0.0196 と $=0.198$ であり、Rosenblatt 逆変換は次式により簡単に行な える。

$x=\exp (\zeta u+\lambda)=\exp (0.198 u-0.0196)$ 
Table 1 Estimating Points and Weights for Point Estimates in Standard Normal Space

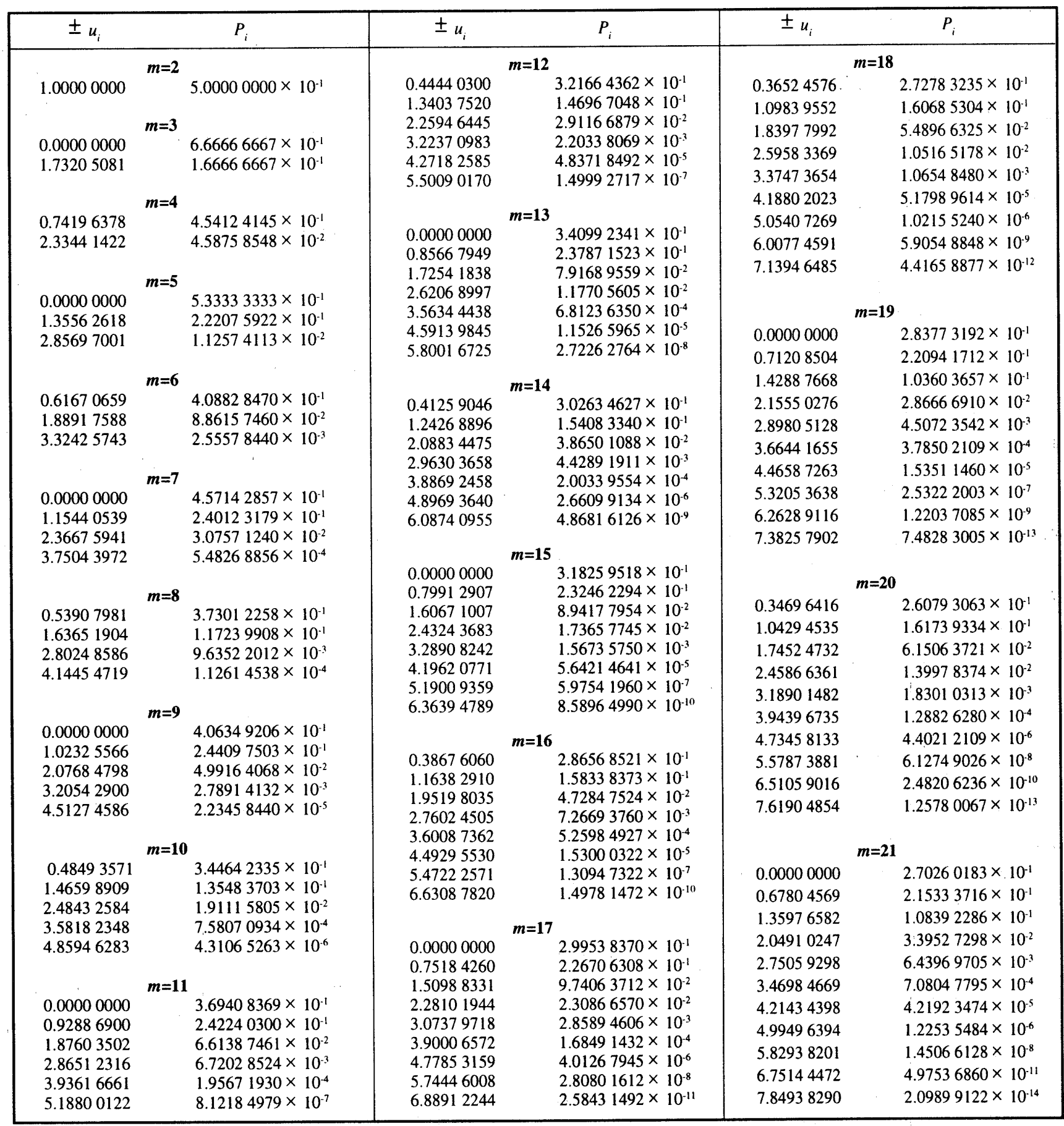

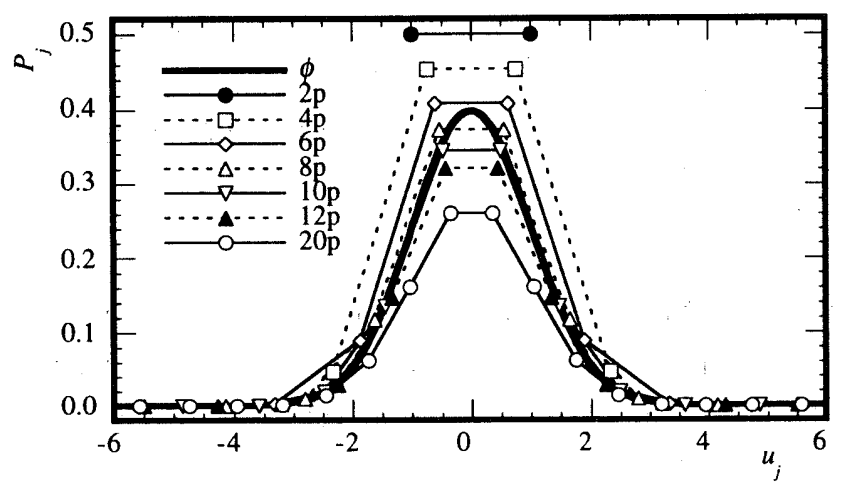

FIg.1 Estimating points and weights of even number

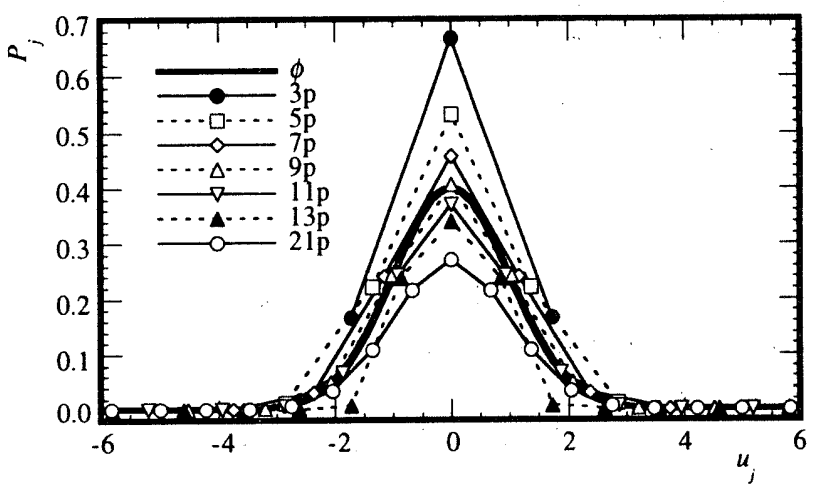

FIg.2 Estimating points and weights of odd number 


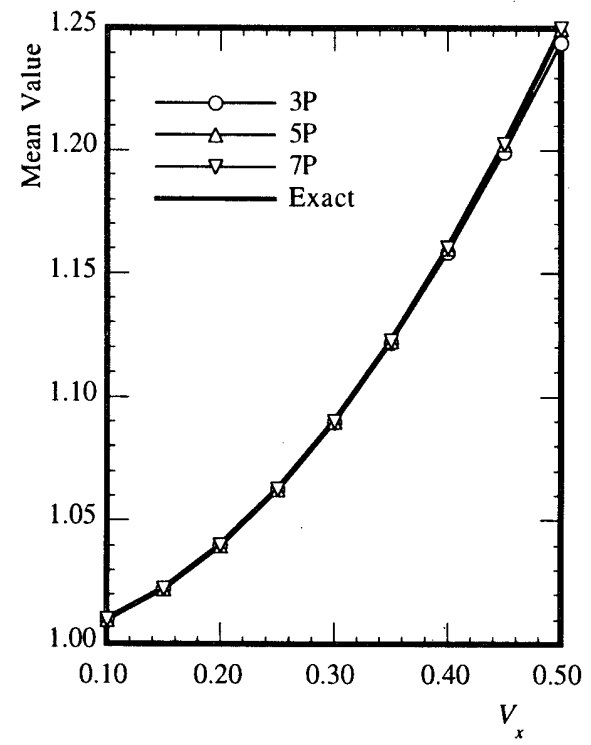

Fig.3 Point estimates for $\mu$

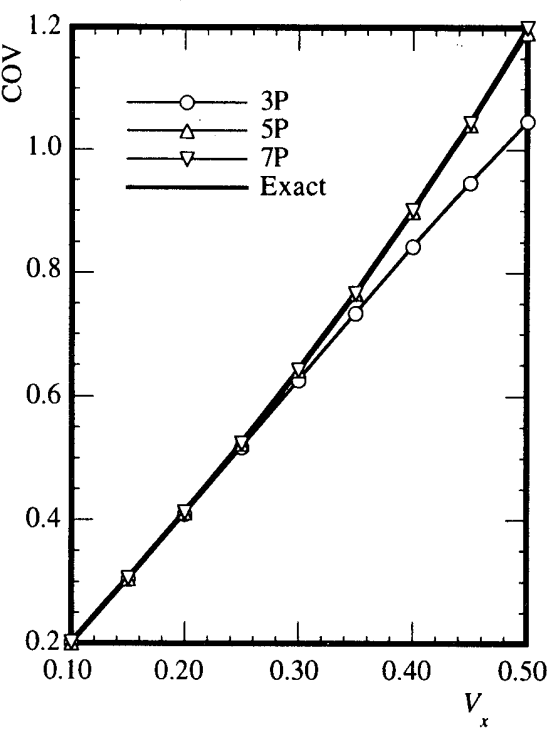

Fig.4 Point estimates for COV

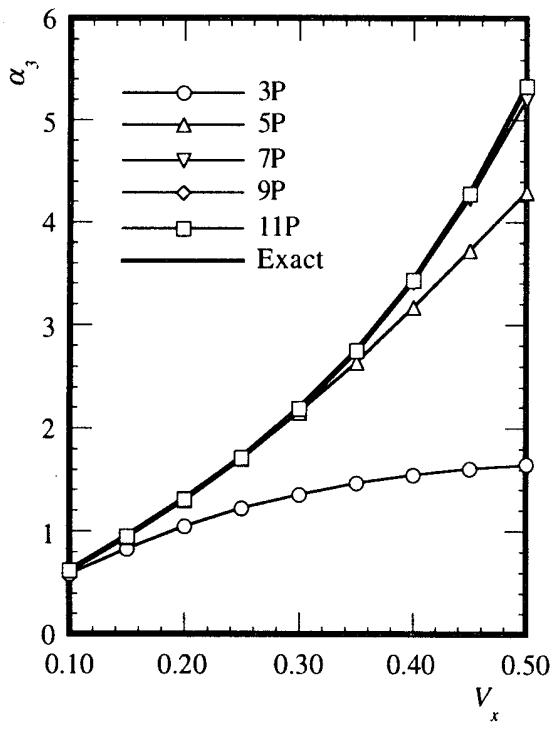

Fig.5 Point estimates for $\alpha_{3}$

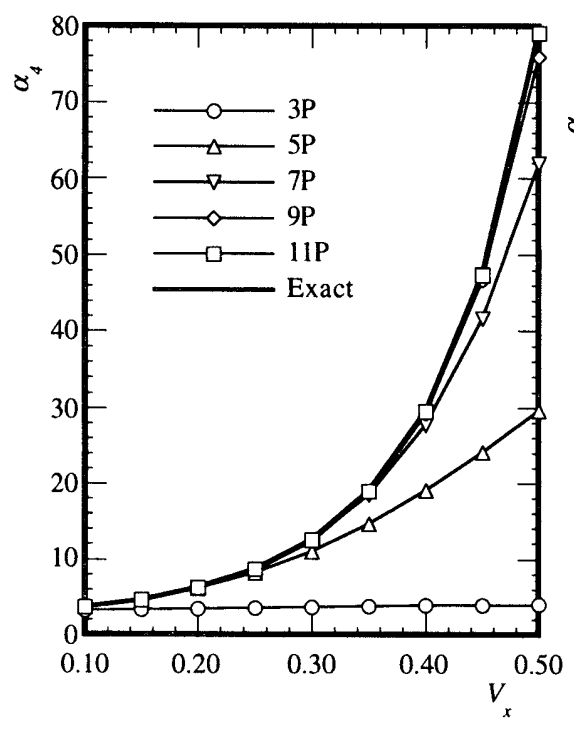

Fig.6 Point estimates for $\alpha_{4}$

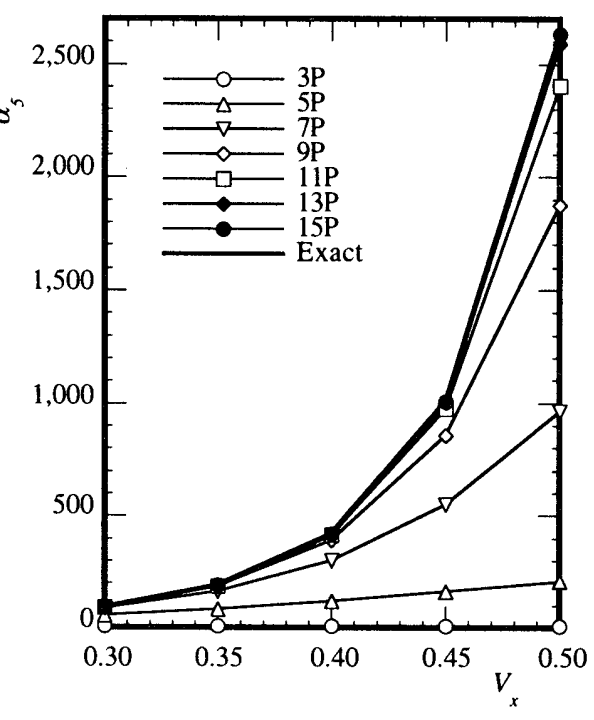

Fig.7 Point estimates for $\alpha_{\varsigma}$

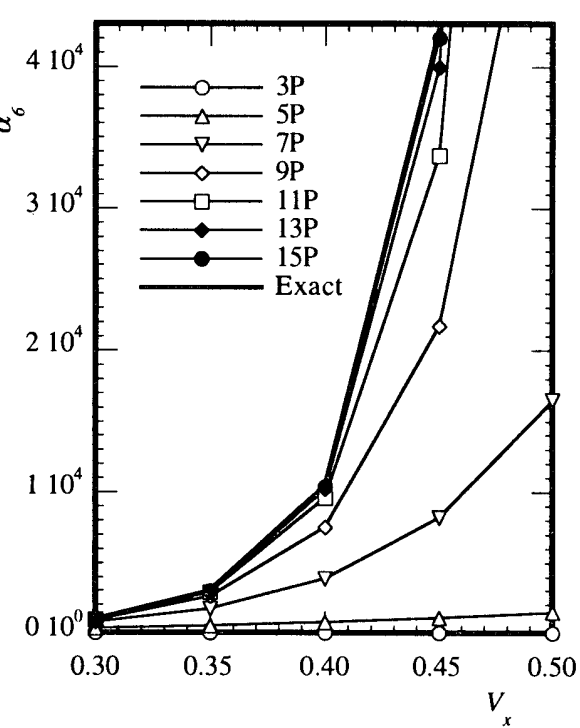

Fig.8 Point estimates for $\alpha_{6}$
Table 1 により、 $m=5$ の時標準正規空間での推定点は $u_{1}=-2.85697$, $u_{2}=-1.35563, u_{3}=0, u_{4}=1.35563, u_{5}=2.85697$ であり、式(35)よりこれら の推定点の対応する元の空間での推定点は $x_{1}=0.5569, x_{2}=0.7497$, $x_{3}=0.9806, x_{4}=1.2826, x_{5}=1.7267$ と得られ、各推定点で対応する式(34) の関数值は $y_{1}=0.3101, y_{2}=0.5621, y_{3}=0.9615, y_{4}=1.6450, y_{5}=2.9814$ とな る。これらの関数值及び Table 1 に示される重み $P_{1}=0.011257$, $P_{2}=0.22208, P_{3}=0.40883, P_{4}=0.22208, P_{5}=0.011257$ を式 (8), (9) に代入 し、 $y$ の 6 次までのモーメントは $\mu=1.04, \sigma=0.4286, \alpha_{3}=1.3037$, $\alpha_{4}=6.0577, \alpha_{\mathrm{s}}=22.159, \alpha_{6}=99.652$ のように計算できる。

$x$ の変動係数 $V$ をパラメータとし、従来の 3 点推定と標準化 $5,7,9$, $11,13,15$ 点推定を用いて、6 次までの無次元モーメントの推定值を Fig.3からFig.8に示す。Fig.3から Fig.8により以下のようなことが読 み取れる。

(1)変動係数Vが大きくなるにつれて点推定の精度が悪くなる。こ

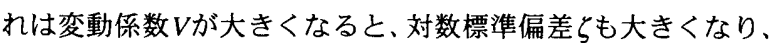
式(35)の Rosenblatt 逆変換関数あるいは式(34)の性能関数の非
線形性が強くなるからである。

(2)従来の点推定法は平均値と標準偏差だけに適当な推定結果を与 えており、標準化点推定は従来の点推定の結果をかなり改善し ていることが分かる。

(3)本例では平均値と標準偏差に対しては5,7点を用いて十分な推 定結果が得られたが、無次元 $3 、 4$ 次モーメントを適切に推定 するには 9,11 点の推定点が必要となり、無次元 5、6 次モ一 メントを適切に推定するには 13,15 点の推定点が必要となる。

\section{2 限界状態関数のモーメント推定}

片持ち梁に曲げモーメント $M_{y}, M_{z}$ と㨭れモ一メントTが作用した場 合を想定し、次のせん断応力に関する限界状態関数を対象として、 多確率変数の関数のモーメント推定の計算手順を示すとともに、その 精度を考察する。

$$
G(\mathbf{X})=M_{\text {yield }}^{2}-M_{y}^{2}-M_{z}^{2}-T^{2}
$$


Table 2 Moments of performance function for Ex. 2

\begin{tabular}{|c|c|c|c|c|c|c|}
\hline method & $\mu$ & $\sigma$ & $\alpha_{3}$ & $\alpha_{4}$ & $\alpha_{\mathrm{s}}$ & $\alpha_{6}$ \\
\hline $3 \mathrm{P}^{[17]}$ & 2469.5 & 2156.3 & 2.1998 & 7.2804 & 20.792 & 62.551 \\
\hline $5 P$ & 2469.5 & 2155.1 & 2.6174 & 14.520 & 81.721 & 480.29 \\
\hline $7 \mathrm{P}$ & 2469.5 & 2156.3 & 2.7263 & 18.319 & 158.76 & 1679.8 \\
\hline $9 P$ & 2469.5 & 2156.3 & 2.7299 & 18.741 & 182.26 & 2541.8 \\
\hline $11 \mathrm{P}$ & 2469.5 & 2156.3 & 2.7299 & 18.765 & 185.73 & 2827.3 \\
\hline $13 P$ & 2469.5 & 2156.3 & 2.7299 & 18.766 & 186.04 & 2882.6 \\
\hline $15 \mathrm{P}$ & 2469.5 & 2156.3 & 2.7299 & 18.766 & 186.06 & 2889.7 \\
\hline Exact & 2469.5 & 2156.3 & 2.7299 & 18.766 & 186.06 & 2890.4 \\
\hline
\end{tabular}

ただし， $M_{\text {yield }} M_{y} M_{z}$ とTを全て変動俰数が 0.35 の対数正規確率変数と

し、平均値をそれぞれ $50,10,10,10$ とする。

式(26), (27)の定義により式(25)を構成する $G_{\mu}, G_{1}, G_{2}, G_{3}$ および $G_{4}$ は次のように得られる。

$$
\begin{aligned}
& G_{\mu}=2200 \\
& G_{1}=M_{\text {yield }}^{2}-300 \\
& G_{2}=2300-M_{y}^{2} \\
& G_{3}=2300-M_{z}^{2} \\
& G_{4}=2300-T^{2}
\end{aligned}
$$

式 (37)の $G_{1}, G_{2}, G_{3}$ および $G_{4}$ は 1 確率変数の関数であり、 $m=5$ の 時 6 次までのモーメントは5.1節で示した手順で次のように容易に計 算できる。

$\mu_{1}=2506.3, \quad \mu_{2}=\mu_{3}=\mu_{4}=2187.8, \quad \sigma_{1}=2149.9, \quad \sigma_{2}=\sigma_{3}=\sigma_{4}=85.996$,

$\alpha_{31}=2.6368, \alpha_{32}=\alpha_{33}=\alpha_{34}=-2.6368, \alpha_{41}=14.630, \alpha_{42}=\alpha_{43}=\alpha_{44}=14.630$,

$\alpha_{51}=82.583, \alpha_{52}=\alpha_{53}=\alpha_{54}=-82.583, \alpha_{61}=486.20, \alpha_{62}=\alpha_{63}=\alpha_{64}=486.20$

式 (28)-(33) より $G$ の 6 次までのモーメントは $\mu=2469.5, \sigma=2155.1$, $\alpha_{3}=2.6174, \alpha_{4}=14.520, \alpha_{5}=81.721, \alpha_{6}=480.29$ のように得られる。

15点までの点推定の結果をTable 2に示し、表中、太文字は精算值 に対して誤差が2\%を越える結果を示している。Table 3より、推定点 の数を增やすことにより、式(37)の限界状態関数の 6 次までのモ一メ ントでも、かなりよい精度で推定できることが分かる。

\section{3 構造システムの限界状態関数のモーメント推定}

次の骨組システムの限界状態関数[1]のモーメントを推定する。

$$
\begin{gathered}
G(\mathbf{X})=\min \left\{g_{1}(\mathbf{X}), g_{2}(\mathbf{X}), g_{3}(\mathbf{X}), g_{4}(\mathbf{X})\right\} \\
g_{1}(\mathbf{X})=2 M_{1}+2 M_{3}-4.5 S \\
g_{2}(\mathbf{X})=2 M_{1}+M_{2}+M_{3}-4.5 S \\
g_{3}(\mathbf{X})=M_{1}+M_{2}+2 M_{3}-4.5 S \\
g_{4}(\mathbf{X})=M_{1}+2 M_{2}+M_{3}-4.5 S
\end{gathered}
$$

$M_{i}, S$ は相互独立的な対数正規確率変数であり、それらの平均值を それぞれと 200,50 と設定し、変動係数をそれぞれ $0.15,0.4$ と設定し た。式(25)を構成する $G_{i}$ は次のように得られる。

$$
G_{\mu}=575
$$

Table 3 Moments of performance function for Ex. 3

\begin{tabular}{|l|c|c|c|c|c|c|}
\hline & $\mu$ & $\sigma$ & $\alpha_{3}$ & $\alpha_{4}$ & $\alpha_{5}$ & $\alpha_{6}$ \\
\hline 3P & \multicolumn{1}{|c|}{537.608} & 114.207 & -0.613 & 3.150 & -4.564 & 16.397 \\
5P & 532.958 & 114.485 & -0.704 & 4.098 & -9.492 & 40.670 \\
7P & 531.076 & 114.374 & -0.698 & 4.140 & -10.131 & 48.536 \\
9P & 530.071 & 114.301 & -0.695 & 4.143 & -10.140 & 49.238 \\
11P & 529.453 & 114.252 & -0.694 & 4.145 & -10.135 & 49.310 \\
13P & 529.037 & 114.218 & -0.693 & 4.146 & -10.132 & 49.346 \\
15P & 528.741 & 114.193 & -0.693 & 4.147 & -10.131 & 49.373 \\
MCS & 540.961 & 114.021 & -0.621 & 4.221 & -9.315 & 49.248 \\
\hline
\end{tabular}

$$
\begin{aligned}
& G_{1}=\min \left\{2 M_{1}+175, M_{1}+375\right\} \\
& G_{2}=\min \left\{575,2 M_{2}+175, M_{2}+375\right\} \\
& G_{3}=\min \left\{2 M_{3}+175, M_{3}+375\right\} \\
& G_{4}=800-4.5 S
\end{aligned}
$$

標準化15点までの点推定の結果をTable 3に示し、7点以上では安 定な推定結果が得られていることが分かる。比較するため、式(38)の 限界状態関数に対してサンプリング数が100,000のモンテカルロ. シ ミュレーション(MCS) を行い、得られた各次モーメントを Table 3に 示す。Table 3 によると、 $\sigma, \alpha_{4}, \alpha_{6}$ については標準化点推定の結果は MCS の結果に良い精度で追従しているが、 $\mu, \alpha_{3}, \alpha_{s}$ について推定点 の数を增やしても、無視できない隔りが残る。これは式(25)の近似式 などの問題点と考えられ、さらなる研究が必要となる。

\section{4 不規則応答の不確定性推定}

動的荷重が作用する 1 自由度線形システムの不規則振動解析を通し て本手法の有効性について考察する。入力はホワイトノイズで，不規 則振動解析により、最大応答の平均值と標準偏差は次のように計算さ れる。

$$
\begin{aligned}
& \mu_{m}=\sqrt{\frac{\pi s}{4(2 \pi f)^{3} \zeta}}\left[\sqrt{2 \ln f D}+\frac{0.5772}{\sqrt{2 \ln f D}}\right] \\
& \sigma_{m}=\frac{\pi}{\sqrt{12 \ln f D}} \sqrt{\frac{\pi s}{4(2 \pi y)^{3} \zeta}}
\end{aligned}
$$

ただし，sは入力のパワースペクトル密度，Dは継続時間，fは固有振 動数, らは隇衰定数である。

パラメータの不確定性を取り入れるために、式 (40), (41)のパラ メ一夕としての $s, D, f, \zeta$ は相互独立的確率変数とする。 $s$ は平均值 0.25 と変動倸数 0.60 極值I型分布とし,$f$ は平均值 $2 \mathrm{~Hz}$ と変動係数 0.1 の正 規分布とする。 $D$ とらを対数正規分布とし，それぞれの平均值は $D=10$ 秒，ら=0.02とし，変動係数はそれぞれ0.3と0.4とする。各パラメータ

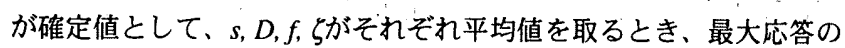
不確定性の結果として $\mu_{m}=0.2705, \sigma_{m}=0.02445, V=0.0904$ が得られてい る。 $s, D, f, \zeta$ 含まれている不確定性を取り入ると、 $\mu_{m}, \sigma_{m}$ は確率変 数 $\mathbf{X}=[s, D, f, \zeta$ 関数となり、最大応答の平均値と標準偏差は次のよ うに与えられる[18]。 
Table 4 Uncertainties of stochastic response for Example 4

\begin{tabular}{|c|c|c|c|c|c|}
\hline & $\mathrm{E}\left[\mu_{m}{ }^{2}(\mathbf{X})\right]$ & $\mathrm{E}\left[\sigma_{m}{ }^{2}(\mathbf{X})\right]$ & $\mu_{M}$ & $\sigma_{M}$ & $V$ \\
\hline 5P & 0.04283 & 0.001718 & 0.1966 & 0.07679 & 0.3906 \\
MCS & 0.04312 & 0.001714 & 0.1969 & 0.07787 & 0.3959 \\
difference & $0.673 \%$ & $0.233 \%$ & $0.152 \%$ & $1.387 \%$ & $1.339 \%$ \\
\hline
\end{tabular}

$$
\begin{aligned}
& \mu_{M}=E\left[\mu_{m}(\mathbf{X})\right] \\
& \sigma_{M}^{2}=E\left[\sigma_{m}^{2}(\mathbf{X})\right]+E\left[\mu_{m}^{2}(\mathbf{X})\right]-\mu_{M}^{2}
\end{aligned}
$$

推定点は確率変数の定義領域以外にあるので、確率変数にに対しては 従来の 3 点推定法は適用できない。標準化 5 点推定を用いて、式 (42), (43)のE[ $\left.\sigma^{2}{ }_{m}(\mathbf{X})\right], E\left[\mu^{2}{ }_{m}(\mathbf{X})\right]$ を推定し、不規則応答の不確定性の結 果をTable 4に示す。比較するため、式(42), (43)のE[ $\left.\sigma_{m}^{2}(\mathbf{X})\right], E\left[\mu_{m}^{2}(\mathbf{X})\right]$ をサンプリング数が 100,000 の MCS で求め、得られた各次モーメン トも Table 4 に示す。Table 4により点推定法の結果は良い精度でMCS の結果と対応している。また、パラメータに含まれている不確定性を 取り入ると、最大応答の変動係数が 0.3906 となり、確定的パラメータ の場合の0.0904よりかなり大きくなることが分かる。

\section{6. まとめ}

本論文の考察により得られた結論は以下の通りである。

1) 標準化点推定法は有限数の点で評価される性能関数値の単純代 数計算のみで構成されており、性能関数の陽的表現および導関 数が必要とせず、性能関数のモ一メントを推定するには有効な手 段と考えられる。

2) 標準化推定点法における任意数 $m$ の推定点 $u_{j}$ は Hermite 多項式 $H_{e m}(u)$ の分点、即ち $H_{e m}(u)=0$ の根である。

3) 標準化推定点法における任意数の推定点と重みの一般的関係を 提示し、21点までの推定点と重みを提供した。これらの推定点と 重みは原空間の確率変数の分布には左右されず、非線形が強い性 能関数の高次モーメントを求めるには有用である。

\section{付録：Hermite 多項式 $H(x)$ と $H_{e}(u)^{[20]}$}

本論文で用いている Hermite多項式 $H(x)$ と $H_{e}(u)$ はそれぞれ次のよ うに定義されている。

$$
\begin{aligned}
& H_{m}(x)=\frac{(-1)^{m}}{\exp \left(-x^{2}\right)} \frac{d^{m}\left[\exp \left(-x^{2}\right)\right]}{d x^{m}} \\
& H_{e m}(u)=\frac{(-1)^{m} d^{m}[\phi(u)]}{\phi(u)} d u^{m}
\end{aligned}
$$

$u=\sqrt{2} x$ とすれば、 $H_{m}(x)$ と $H_{e m}(u)$ の間の関係式が得られる。

$$
H_{m}(x)=2^{m / 2} H_{e m}(u)
$$

Table 5 First 5 polynomials of $H_{m}(x)$ and $H_{e m}(u)$

\begin{tabular}{|l|l|l|}
\hline$m$ & \multicolumn{1}{|c|}{$H_{m}(x)$} & \multicolumn{1}{c|}{$H_{e m}(u)$} \\
\hline 1 & $2 x$ & $u$ \\
2 & $4 x^{2}-2$ & $u^{2}-1$ \\
3 & $8 x^{3}-12 x$ & $u^{3}-3 u$ \\
4 & $16 x^{4}-48 x^{2}+12$ & $u^{4}-6 u^{2}+3$ \\
5 & $32 x^{5}-160 x^{3}+120 x$ & $u^{5}-10 u^{3}+15 u$ \\
\hline
\end{tabular}

\section{謝辞}

本論文の査読者からは、本論文の内容と構成についていくつの貴重 なコメントを頂いた。付して感謝の意を表す。

\section{参考文献}

[1] 日本建築学会限界状態設計法小委員会、建築物の限界状態設計指針 （案）、1999.3

[2] 小野徹郎、井戸田秀樹、高次積率標準化手法の提案とそれに基づく信頼 性指標の設定、日本建築学会構造系論文報告集、No. 359, 43-49, 1986.1.

[3] 小野徹郎、井戸田秀樹、高次積率標準化手法の設計法への展開とその有 効性、日本建築学会構造系論文報告集、No. 365, 40-47, 1986.7 .

[4] Tichy, M., (1994) "First-order third-moment reliability method." Structural Safety, Vol. 16, 189-200.

[5] 趙 衍剛、小野徹郎等、確率モーメントを用いる構造信頼性解析法、そ の $1 \sim 3$ 、日本建築学会東海支部研究報告集、Vol. 37, 133-144, 1999.2.

[6] 趙 衍剛、小野徹郎、構造信頼性解析における 3、4 次モ一メント法の 考察、日本建築学会構造系諭文報告集、No. 530, 2000.4

[7] Shinozuka, M., "Structural response variability." J. Engrg. Mech., ASCE, Vol. 113, No. 6, 825-842, 1987.

[8] Ibrahim, R.A., Structural dynamics with parameter uncertainties, Appl. Mech. Rev., Vol. 40, No. 3, 309-328,1987.

[9] 高田毅士、不確定モデルの解析、応用力学シリーズ、非線形・不確定モ デリング、1999.2.

[10] Takada, T., "Weighted integral method in stochastic finite element analysis." Probabilistic Engineering Mechastics, Vol. 5, No. 3, 146-156, 1990.

[11] Suzuki, M., and Takada, T., "Response of pile embedded in stochastic ground media." Structural Safety, Vol. 19, 105-120, 1997.

[12] Rosenblueth, E., "Point estimates for probability moments." Proc. of National Academy of Science of USA, Vol. 72, No.10, 3812-3814, 1975.

[13] Rosenblueth, E., "Two-point estimate in probabilities." Appl. Math. Modeling, Vol. 5, 329-335, 1980.

[14] Gorman, M.R., "Reliability of structural systems", Ph.D Thesis, Case Western Reserve University, 320-332, 1980.

[15] 小野徹郎、井戸田秀樹、高次積率を用いた鋼圧縮材及び曲げ材の抵抗強度 に関する統計論的研究、日本建築学会構造系論文報告集、No.370, 19-27, 1986.12 .

[16] Li, K.S., "Point-estimate method for calculating statistical moments." J. Engrg. Mech., ASCE, Vol. 118, No. 7, 1506-1511, 1992.

[17] 井戸田秀樹、小野徹郎、早川由則、高次不静定骨組の信頼性解析法に関す る研究、構造物の安全性及び信頼性、JCOSSAR'91,497-502.

[18] Zhao, Y.G., Ono, T. and Idota, H., (1999), "Response uncertainty and time variant reliability analysis for hysteretic MDF structures." Earthquake Engineering and Structural Dynamics, Vol. 28, No. 10, 1187-1213.

[19] Zhao, Y.G. and Ono, T., (2000). "New point estimates for probability moments." J. Engrg. Mech., ASCE, Vol.126, No.4, 2000.4

[20] Abramowitz, M. and Stegum, I.E. (1972). Handbook of Mathematical Functions, Dover, New York, tenth printing.

例えば、 5 次までの $H_{m}(x)$ と $H_{e m}(u)$ は Table 5 に示す。 